\title{
A MEDIUM SUPPLEMENTED WITH VEGETABLE EXTRACT USED FOR CELLULOSE PRODUCTION OF RHODOCOCCUS SP. MI 2
}

\author{
MEIO SUPLEMENTADO COM EXTRATO VEGETAL UTILIZADO NA PRODUÇÃO \\ DE CELULOSE DE RHODOCOCCUS SP. MI 2
}

\author{
Somporn TANSKUL ${ }^{1}$; Tassanaporn DAMTHONGSEN ${ }^{1}$; Nathakan JATURONLAK $^{1}$ \\ Department of Molecular Biotechnology and Bioinformatics, Faculty of Science, Prince of Songkla University, Hat Yai 90112 Thailand. \\ somporn.t@psu.ac.th
}

\begin{abstract}
In this study, the most suitable vegetable extract was screened to use as non-conventional nutrient sources for cellulose production of Rhodococcus sp. MI 2. SH medium or a synthetic medium was used as a conventional or control medium. Cha-poo (Piper sarmentosum Roxb.) and sweet potato (Ipomoea batatas Lam.) were 2 out of 14 vegetable extracts chosen as medium supplements. Rhodococcus sp. MI 2 gave the highest cellulose yield in a medium supplemented with Cha-poo extract. The optimum culture conditions in the medium supplemented with Cha-poo extract at room temperature $\left(25^{\circ} \mathrm{C}\right)$ under static condition were $5 \%\left(\mathrm{v} \mathrm{v}^{-1}\right)$ inoculum size, a 6 -day -incubation period, $\mathrm{pH} \mathrm{3,3 \%}$ sucrose, and $0.5 \%\left(\mathrm{NH}_{4}\right)_{2} \mathrm{SO}_{4}$. The cellulose yield in the medium supplemented with Cha-poo extract was increased about 3 times (6.83 $\mathrm{g} \mathrm{L}^{-1}$ during 6 days) higher than that obtained before optimizing $\left(2.39 \mathrm{~g} \mathrm{~L}^{-1}\right.$ during 6 days). The medium supplemented with Cha-poo extract cost one quarter $\left(0.5 \mathrm{USD} \mathrm{L}^{-1}\right.$ of medium) of the SH medium (1.9 USD L of $^{-1}$ medium). The structure of the microfibrils of cellulose produced by Rhodococcus sp. MI 2 in a medium supplemented with Cha-poo extract observed by SEM had larger, less crowded fibrils than those produced in the medium supplemented with sweet potato extract. In addition, the microfibrils of the former had many beehive shaped knots whereas those of the latter had mantle-like surrounding the fibrils.
\end{abstract}

KEYWORDS: Bacterial cellulose. Cha-poo. Piper sarmentosum. Sweet potato. Ipomoea batatas.

\section{INTRODUCTION}

Cellulose is the basic structural component of the cell walls of most plants and fungi, and some algae. It is also found in some bacteria such as Acetobacter, Achromobacter, Aerobacter, Agrobacterium, Azotobacter, Escherichia, Rhizobium, Salmonella, Sarcina (MOOSAVINASAB; YOUSEFI, 2011; NARITOMI et al., 1998; SANI; DAHMAN, 2010), and Rhodococcus sp. MI 2 (TANSKUL et al., 2013). Bacterial cellulose has been used as food (IGUCHI et al., 2000), a stabilizer in food and cosmetics, dental implants (BACKDAHL et al., 2006), wound healing membranes (LI et al., 2015), electronic paper (SHAH; BROWN, 2005), and optically transparent nanocomposites (FERNANDES et al., 2009; NOGI et al., 2005; NOGI; YANO, 2008).

In 2013, we have reported about Rhodococcus sp. MI 2 from Manilkara zapota or sapodilla which is able to produce cellulose in $\mathrm{SH}$ (Schramm and Hestrin) medium under static, agitated and stirred conditions with a higher yield than the reference strain, Acetobacter xylinum TISTR 998 (TANSKUL et al., 2013). In addition, $0.5 \% \mathrm{CaCO}_{3}$ added in the $\mathrm{SH}$ medium increases bacterial cellulose of Rhodococcus sp. MI 2. However, the industrial production of bacterial cellulose is limited due to the high cost of carbon substrates. Agricultural waste products (KONGRUANG, 2008; KESHK et al., 2006), beet molasses (KUROSUMI et al., 2009), fruit juices (HONG; QIU, 2008), konjac powder (plant powder) (MOON et al., 2006), saccharified food wastes (CASTRO et al., 2011), agroindustrial residues (ADEJOYE et al., 2006) have been used as nonconventional nutrient sources for bacterial cellulose production in order to decrease the cost of production. Furthermore, addition of sugar sources such as glucose and fructose (HONG; QIU, 2008; BAE; SHODA, 2004; ISHIHARA et al., 2002), a nitrogen source (KUROSUMI et al., 2009) or calcium carbonate (TANSKUL et al., 2013; HONG; QIU, 2008) increases the cellulose production. There was no mention given regarding vegetable extracts used as medium supplements. This study aimed to screen the most suitable kind of vegetable extract that could be used instead of the major ingredients such as peptone and yeast extract in the SH medium for cellulose production by Rhodococcus sp. MI 2.

\section{MATERIAL AND METHODS}

The SH medium used for cultivating Rhodococcus sp. MI 2 per liter contains $15 \mathrm{~g}$ sucrose, $7 \mathrm{~g}$ peptone, $9 \mathrm{~g}$ yeast extract, $2.7 \mathrm{~g}$ anhydrous disodium phosphate, and $1.5 \mathrm{~g}$ citric acid 
monohydrate (TANSKUL et al., 2013). The pH of the media was adjusted to 3.5 with $0.1 \mathrm{~N} \mathrm{HCl}$. A medium supplemented with vegetable extract per liter contained $15 \mathrm{~g}$ sucrose, $5 \mathrm{~g}$ ammonium sulfate, and $10 \mathrm{~mL}$ acetic acid. The vegetable extract was prepared by weighing $200 \mathrm{~g}$ of leafy or non-leafy vegetables. Leafy vegetables were chopped, minced, and extracted in $1 \mathrm{~L}$ of distilled water. Non-leafy vegetables were washed, peeled off, sliced into small pieces, and boiled in $1 \mathrm{~L}$ of distilled water for 20 min. All chemicals used were of analytical grades.

A bacterial strain used in this study was obtained from a previous screening (TANSKUL et al., 2013). The starter was prepared by subculturing $5 \% \mathrm{v} \mathrm{v}^{-1}$ of Rhodococcus sp. MI 2 to a SH medium under static condition at room temperature for 2-3 days. A $5 \% \mathrm{v} \mathrm{v}^{-1}$ of the starter culture was then inoculated into a 250-ml flask containing $100 \mathrm{ml}$ of the $\mathrm{SH}$ medium or a medium supplemented with vegetable extract under the same condition. The cellulose was harvested after 14 -day -incubation period by picking out of the medium and boiling in $0.1 \mathrm{~N} \mathrm{NaOH}$ for $10 \mathrm{~min}$. It was immersed in distilled water for at least $2 \mathrm{~h}$ or overnight, and then rinsed extensively with distilled water or until the $\mathrm{pH}$ became neutral. It was then dried at $60^{\circ} \mathrm{C}$ for $36-48 \mathrm{~h}$ or until the weight did not change. The dried weight of cellulose was measured. The experiments were done in triplicate.

The compositions, for example, crude fat, crude protein, moisture, ash, carbohydrate (by difference), calcium, phosphorus and iron of the vegetable were determined according to the AOAC International Methods. Crude fat was analyzed by Soxhlet extraction method with petroleum ether and crude protein was analyzed by the $\mathrm{CN}$ analyzer. The moisture and ash were investigated by drying at $103-105^{\circ} \mathrm{C}$ and heating at $750^{\circ} \mathrm{C}$, respectively. The amount of calcium and iron were determined by inductively coupled plasma optical emission spectroscopy (ICP-OES) (Perkin Elmer Optima 4300 DV, USA). The amount of phosphorus was measured by the photometric method. All experiments were done in triplicate.

The optimum conditions for bacterial cellulose production investigated were inoculum size: $5,10,15$, and $20 \%$ after a 14 -day -incubation period; incubation time: 5-, 6-, 7-, and 8-day incubation period; $\mathrm{pH}: 3,3.5,4,4.5,5,5.5$, and 6 ; amount of sucrose: $1.5,3,5,7,9$, and $11 \%$; amount of $\left(\mathrm{NH}_{4}\right)_{2} \mathrm{SO}_{4}: 0,0.5,1$, and $1.5 \%$. The dried weight of cellulose was determined as mentioned above. The experiments were done in triplicate. The costs of the SH medium and the medium supplemented with the chosen vegetable extract were then calculated and compared.

The structure of microfibrils was observed by scanning electron microscope. After 2- day incubation period, the cellulose pellicle was harvested as mentioned above. It was then prepared to be drying in a semi -automatic point drying apparatus (SAMDRI-790). It was finally mounted on aluminum studs and coated with gold under high vacuum conditions.

Means and standard deviations of each treatment with three replications were calculated with SPSS, version 11.5 (SPSS Inc., Chicago, H., USA). The differences of the mean values were compared and analyzed by both analysis of variance (ANOVA) and Duncan's multiple range test (DMRT). Differences at the 95\% confidence level were considered to be significant.

\section{RESULTS AND DISCUSSION}

There were 14 kinds of vegetables: Leucaena glauca, Senna siamea Lam., Sesbania grandiflora, Cha-poo (Piper sarmentosum Roxb.), Centella asiatica Linn., Tiliacora triandra (Colebr.), Ocimum basilicum, Morinda citrifolia Linn., PakLheang (Gnetum gnemon L.), sweet potato (Ipomoea batatas Lam.), Neptunia oleracea Lour., Brassica alboglabra, Brassica juncea var. rugosa, and Azadirachta indica prepared as mentioned above to use as non-conventional nutrient sources for cellulose production by Rhodococcus sp. MI 2 . The results showed after 14 -day -incubation period that Rhodococcus sp. MI 2 could not produce cellulose in a medium supplemented with any kinds of these vegetable extracts, except with Cha-poo and sweet potato extract. After a 14 -day -incubation period the medium supplemented with Cha-poo extract and sweet potato extract yielded $11.33 \pm$ 0.076 and $10.42 \pm 0.079 \mathrm{~g} \mathrm{~L}^{-1}$ cellulose, respectively.

Rhodococcus sp. MI 2 was cultivated statically in the medium supplemented with Chapoo extract at room temperature $\left(25^{\circ} \mathrm{C}\right)$. There were no significant differences in the cellulose yield among the 5, 10, 15 and $20 \%$ inoculum size used for cultivation $(p=0.180)$ (data not shown). A 6 -day incubation period gave the highest cellulose yield, $2.39 \pm 0.155 \mathrm{~g} \mathrm{~L}^{-1}$ which was significantly higher than of 5-, 7- and 8 -day -incubation period (data not shown). Rhodococcus sp. MI 2 showed the highest cellulose production, $6.71 \pm 0.913 \mathrm{~g} \mathrm{~L}^{-1}$ for a 6 -day -incubation period at the initial $\mathrm{pH} 3$ which was significantly higher than those of the other initial $\mathrm{pH}$ values of 3.5-6 (Figure 1a). The different amounts 
of sucrose, 3, 5 and $7 \%$, added to the medium supplemented with Cha-poo extract produced no significant difference of cellulose yields (Figure 1b), but these showed significantly $(p<0.05)$ higher cellulose production than the $1.5,9$ and $11 \%$ sucrose. Comparison of the cellulose yield after cultivating Rhodococcus sp. MI 2 in the medium with different amounts of ammonium sulfate showed that $0.5 \%$ ammonium sulfate gave a significantly higher yield than that of 0,1 or $1.5 \%$ ammonium sulfate $(p<0.05)$ (Figure $1 c)$.

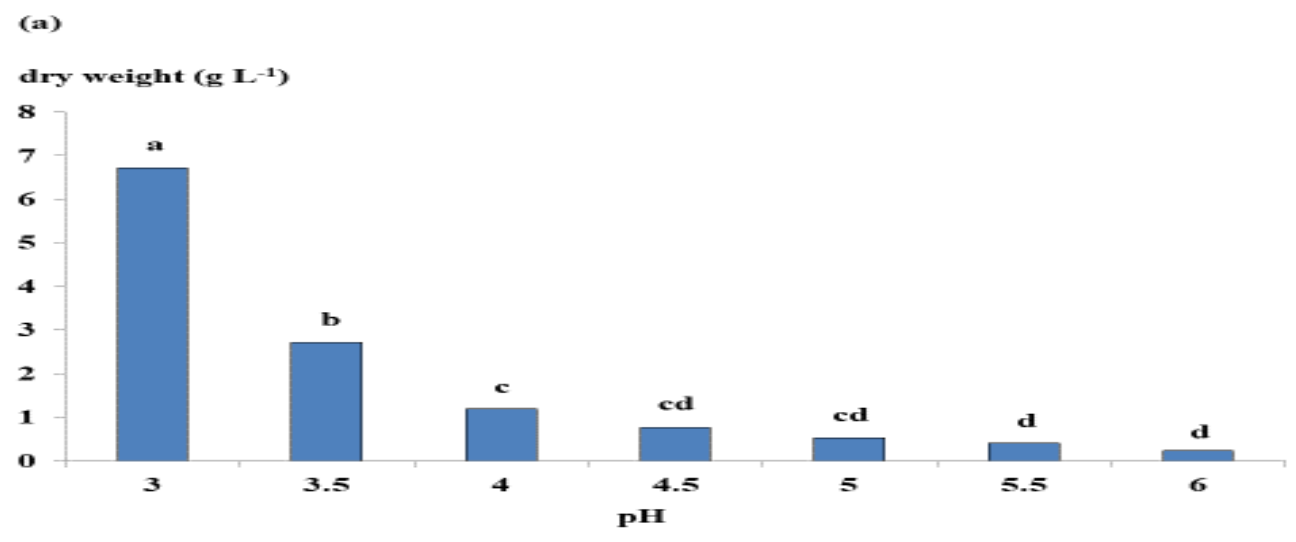

(b)

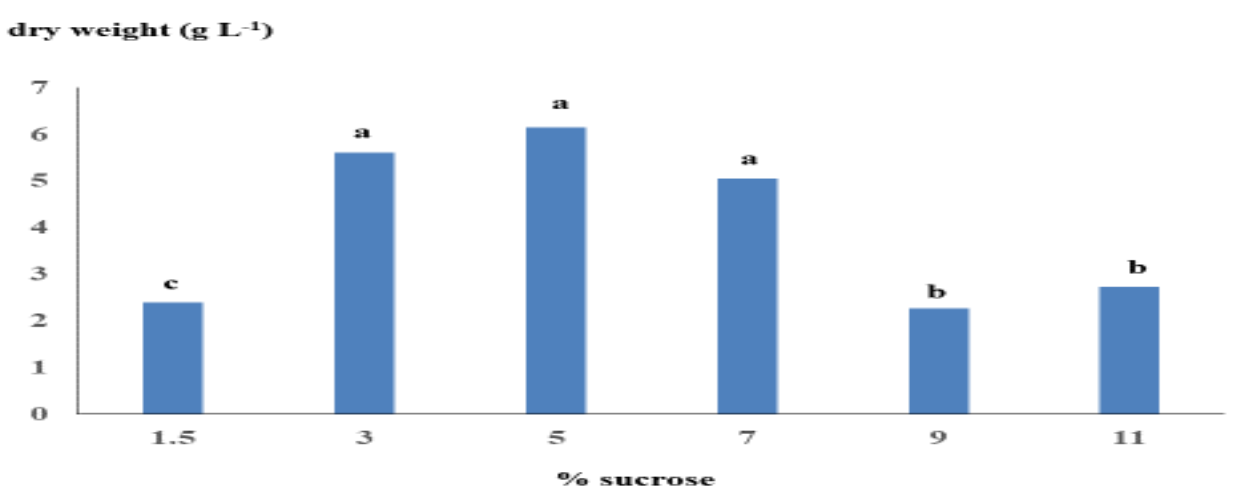

(c)

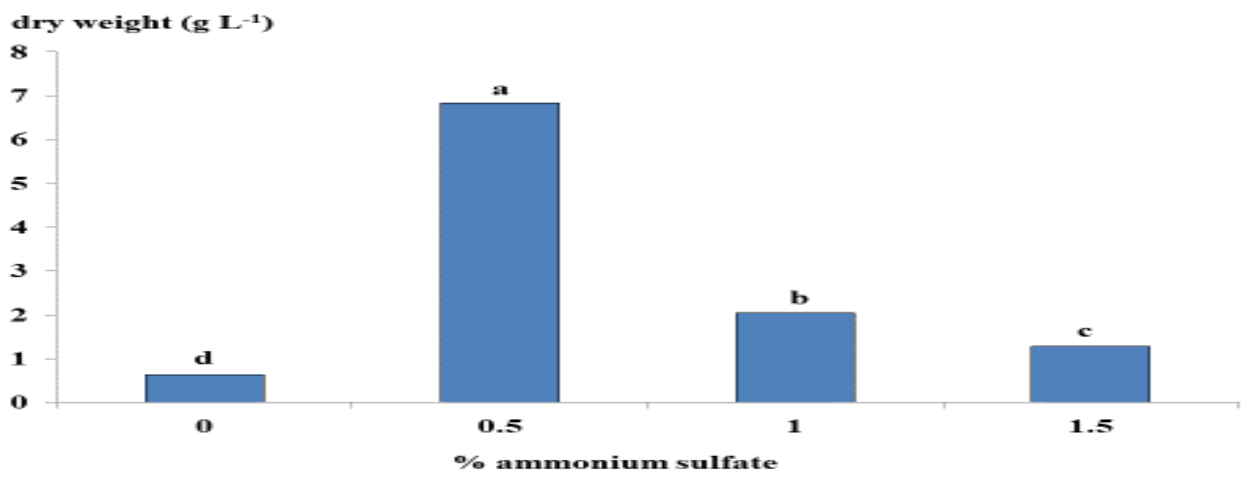

Figure 1. Effect of culture conditions on cellulose production after 6 -day -incubation period by Rhodococcus sp. MI 2: (a) $\mathrm{pH}$; (b) \% sucrose; (c) \% ammonium sulfate

The main compositions of Cha-poo and sweet potato investigated are set out in Table 1 . The Cha-poo contained significantly higher crude fat $\left(0.94 \pm 0.009 \%\left(\mathrm{w} \mathrm{w}^{-1}\right)\right)$ than that of sweet potato $\left(0.05 \pm 0.001 \%\left(\mathrm{w} \mathrm{w}^{-1}\right)\right)$. The results showed that the crude protein content in Cha-poo $(5.81 \pm$ $\left.0.063 \%\left(\mathrm{w} \mathrm{w}^{-1}\right)\right)$ was significantly 3.3 times higher than that in sweet potato $\left(1.75 \pm 0.031 \%\left(\mathrm{w} \mathrm{w}^{-1}\right)\right)$. In contrast, the carbohydrate content in sweet potato $\left(32.27+0.012 \%\left(\mathrm{w} \mathrm{w}^{-1}\right)\right)$ was significantly higher than that in Cha-poo $\left(13.77 \pm 0.129 \%\left(\mathrm{w} \mathrm{w}^{-1}\right)\right)(p<$ $0.05)$. Moreover, the calcium content in Cha-poo $\left(22.15 \pm 0.451 \mathrm{mg} \mathrm{kg}^{-1}\right)$ was 8 times higher than that in sweet potato $\left(2.70+0.018 \mathrm{mg} \mathrm{kg}^{-1}\right)$. In contrast, sweet potato contained significantly higher amounts 
of phosphorus $\left(6.81 \pm 0.038 \mathrm{mg} \mathrm{kg}^{-1}\right)$ and iron $(0.25$ $\left.\pm 0.001 \mathrm{mg} \mathrm{kg}^{-1}\right)$ than those of Cha-poo $(p<0.05)$. The cost of the SH medium was about 1.9 USD L $^{-1}$ whereas that of the medium supplemented with Cha-poo leaf extract was about $0.5 \mathrm{USD} \mathrm{L}^{-1}$ (Table 2).

The microfibril structure produced by Rhodococcus sp. MI 2 in a medium supplemented with Cha-poo extract had larger, less crowded fibrils (Figure 2a-c) than those produced in the medium supplemented with sweet potato extract (Fig. 2d-f). In addition, the microfibrils of the former had many beehive shaped knots (Figure 2a-c) whereas those of the latter had mantle-like surrounding the fibrils (Figure 2d-f).

Table 1. Comparison of the compositions of Cha-poo and sweet potato

\begin{tabular}{lcc}
\hline \multicolumn{1}{c}{ Compositions } & Cha-poo & Sweet potato \\
\hline Crude fat $\left(\% \mathrm{w} \mathrm{w}^{-1}\right)$ & $0.94 \pm 0.009$ & $0.05 \pm 0.001$ \\
Crude protein $\left(\% \mathrm{w} \mathrm{w}^{-1}\right)$ & $5.81 \pm 0.063$ & $1.75 \pm 0.031$ \\
Moisture $\left(\% \mathrm{w} \mathrm{w}^{-1}\right)$ & $78.64 \pm 0.095$ & $65.91 \pm 0.019$ \\
Ash $\left(\% \mathrm{w} \mathrm{w}^{-1}\right)$ & $0.83 \pm 0.003$ & $0.02 \pm 0.000$ \\
Carbohydrate $($ by difference) & $13.77 \pm 0.129$ & $32.27 \pm 0.012$ \\
Calcium $\left(\mathrm{mg} \mathrm{kg}^{-1}\right)$ & $22.15 \pm 0.451$ & $2.70 \pm 0.018$ \\
Phosphorus $\left(\mathrm{mg} \mathrm{kg}^{-1}\right)$ & $2.35 \pm 0.033$ & $6.81 \pm 0.038$ \\
Iron $\left(\mathrm{mg} \mathrm{kg}^{-1}\right)$ & $0.16 \pm 0.002$ & $0.25 \pm 0.001$ \\
\hline
\end{tabular}

Table 2. Costs of ingredients of the SH medium (TANSKUL et al., 2013) and the medium supplemented with Cha-poo extract

\begin{tabular}{llc}
\hline \multicolumn{1}{c}{ Medium } & \multicolumn{1}{c}{ Ingredient } & Cost (USD L ${ }^{-1}$ of medium) \\
\hline SH medium & 15 g sucrose & 0.011 \\
& $7 \mathrm{~g}$ peptone & 0.776 \\
& $9 \mathrm{~g}$ yeast extract & 1.025 \\
& $2.7 \mathrm{~g}$ anhydrous disodium phosphate & 0.050 \\
& $1.5 \mathrm{~g}$ citric acid monohydrate & 0.035 \\
\hline medium supplemented with Cha-poo & Total & 1.897 \\
& $200 \mathrm{~g}$ Cha-poo leaves & 0.292 \\
\hline extract & $30 \mathrm{~g}$ sucrose & 0.022 \\
& $5 \mathrm{~g}$ ammonium sulfate & 0.102 \\
& $10 \mathrm{ml}$ acetic acid & 0.056 \\
\hline & Total & 0.472 \\
\hline
\end{tabular}



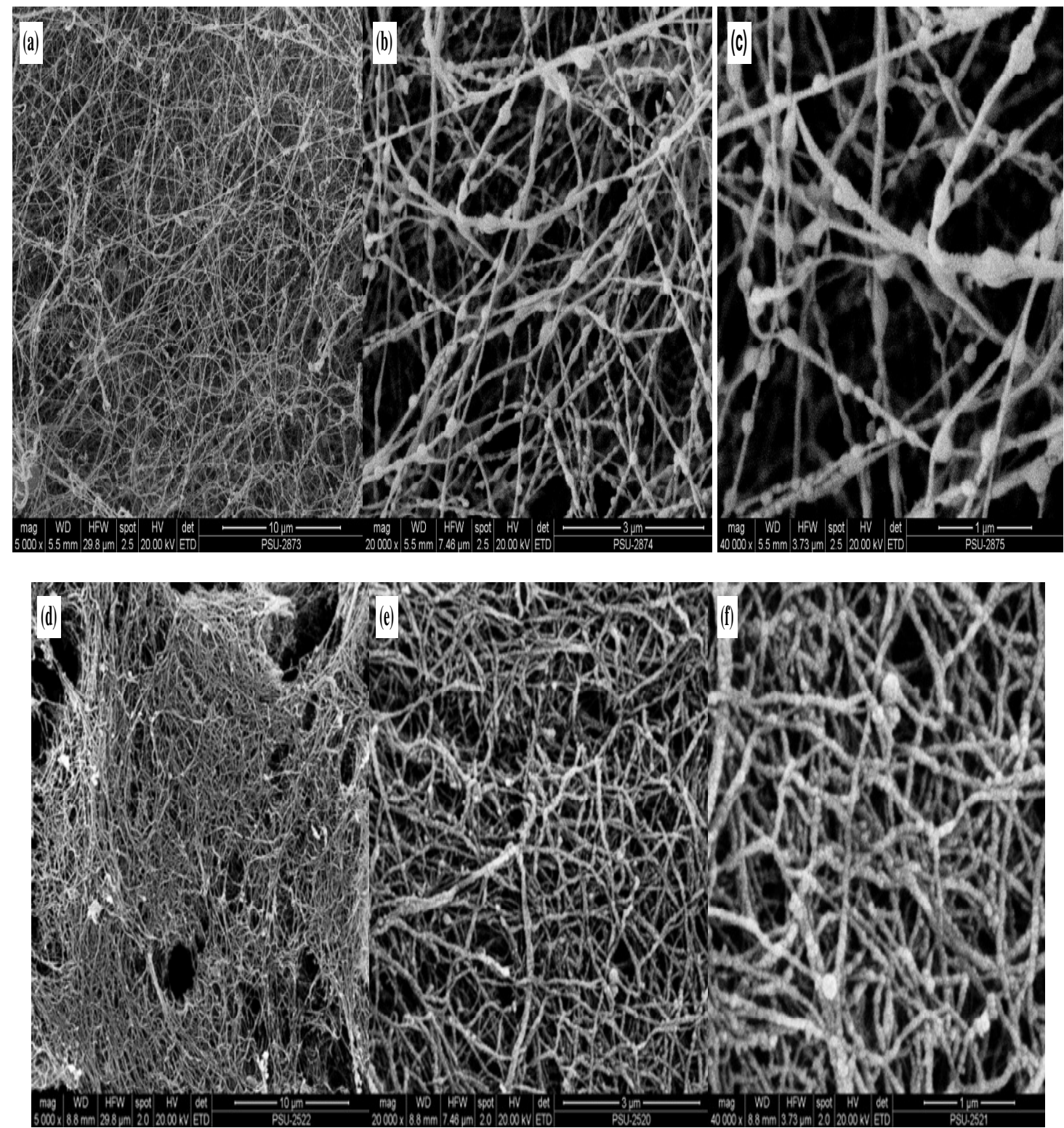

Figure 2. SEM images of bacterial cellulose from Rhodococcus sp. MI 2 in a medium supplemented with Chapoo extract at a magnification of: (a) 5,000x (b) 20,000x (c) 40,000x; and in a medium supplemented with sweet potato extract at a magnification of: (d) 5,000x (e) 20,000x (f) 40,000x

\section{DISCUSSION}

Rhodococcus sp. MI 2 gave cellulose yield in a medium supplemented with Cha-poo extract higher than that with sweet potato extract. However, Cha-poo and sweet potato were good nutrient sources for Rhodococcus sp. MI 2 to grow and produce cellulose. In contrast, the other 12 vegetable extracts were not good for the strain. It might be because of their compositions or antibacterial substance(s). Although, the amount of all ingredients in Pak-Lheang differed not so much from that of Cha-poo, and contained more calcium than that of sweet potato, but about 6 times less than that of Cha-poo (data not shown). The medium supplemented with Pak-Lheang extract was not good for the growth of Rhodococcus sp. MI 2. It therefore probably contained inhibitory compounds towards Rhodococcus sp. MI 2. Sakagami et al. have reported that gnemonol $\mathrm{B}$ isolated from Gnetum gnemon and gnetin E obtained from the Gnetum species show antibacterial activities against vancomycin-resistant Enterococci (Gram-negative bacteria) and methicillin-resistant Staphylococcus aureus (Gram-positive bacteria) (SAKAGAMI et al., 2007).

The $5-20 \%$ of the inoculum size made no significant difference to the cellulose production. Thus, $5 \%$ inoculum size was chosen. The maximum dry weight of bacterial cellulose occurred after the 6 
-day -incubation period, but the thickness and the wet weight of BC were less than after a 7 -, 8 -day incubation period (data not shown). This was consistent with our previous report (TANSKUL et al., 2013). The optimum $\mathrm{pH}$ of a medium supplemented with Cha-poo extract was at 3 which was slightly lower than that of the $\mathrm{SH}$ medium for Rhodococcus sp. MI 2 (TANSKUL et al., 2013). The optimum amount of sucrose was in the range of 3-7\% which was higher than that of the $\mathrm{SH}$ medium (TANSKUL et al., 2013). Therefore, 3\% sucrose was chosen for this study. The strain was not able to produce cellulose in the medium without $\left(\mathrm{NH}_{4}\right)_{2} \mathrm{SO}_{4}$ meaning that the initial nitrogen content of Cha-poo leaf extract was too low for Rhodococcus sp. MI 2 to produce cellulose, but the $0.5 \%\left(\mathrm{NH}_{4}\right)_{2} \mathrm{SO}_{4}$ gave the highest yield. These results are consistent with a study on pineapple peel and sugar cane juice which do not contain sufficient nitrogen for Gluconacetobacter swingsii sp. to produce cellulose (MOON et al., 2006). The cellulose yield in the medium supplemented with Cha-poo extract was increased about 3 times (6.83 $\mathrm{g} \mathrm{L}^{-1}$ during 6 days) higher than that obtained before optimizing (2.39 $\mathrm{g}$ $\mathrm{L}^{-1}$ during 6 days). In addition, a medium supplemented with Cha-poo extract cost about a quarter of that of the $\mathrm{SH}$ medium.

The cellulose pellicle produced by Rhodococcus sp. MI 2 in a medium supplemented with Cha-poo extract had almost the same reticulated structure of a densely packed network of microfibrils as that produced in a medium supplemented with sweet potato extract observed with the naked eye (data not shown). The microfibril structure of cellulose produced by Rhodococcus sp. MI 2 in a medium supplemented with Cha-poo extract had the unique shape of knots and had larger, less crowded fibrils than those produced in the medium supplemented with sweet potato extract. Unlike the microfibrils of cellulose produced by Gluconacetobacter hansenii PJK (KCTC 10505BP) in waste from beer fermentation broth consists of thinner and more crowded fibrils than those in a chemically defined medium (SHEZAD et al., 2010).

Extracts of agricultural material added to a medium could be used by Rhodococcus sp. MI 2 to produce cellulose. The medium was simple and contained ingredients that supported good growth and cellulose production. Thus, it is now possible to obtain bacterial cellulose on a larger scale in a much low-cost medium.

\section{ACKNOWLEDGEMENTS}

The authors wish to thank Faculty of Science, Prince of Songkla University, Hat Yai, Thailand for financial support of this study. We also thank Dr. Brian Hodgson and Anna Chatthong for assistance with the English.

RESUMO: Neste estudo, o extrato vegetal mais adequado foi triado para uso como fontes não convencionais de nutrientes para produção de celulose de Rhodococcus sp. MI 2. Utilizou-se um meio SH ou meio sintético como meio convencional ou de controle. Cha-poo (Piper sarmentosum Roxb.) e batata-doce (Ipomoea batatas Lam.) foram 2 dos 14 extratos vegetais escolhidos como suplementos do meio. Rhodococcus sp. MI 2 deu o maior rendimento de celulose em um meio suplementado com extrato de Cha-poo. As condições ótimas de cultivo no meio suplementado com extrato de Cha-poo em temperatura ambiente $\left(25^{\circ} \mathrm{C}\right)$ em condição estática foram $5 \%$ (v v-1) do tamanho do inóculo, um período de 6 dias de incubação, $\mathrm{pH} 3,3 \%$ de sacarose, e 0,5\% (NH4) 2SO4. O rendimento de celulose no meio suplementado com extrato de Cha-poo foi aumentado cerca de 3 vezes (6,83 g L-1 durante 6 dias), maior do que o obtido antes da otimização (2,39 g L-1 durante 6 dias). O meio suplementado com extrato de Cha-poo custou um quarto (0,5 USD L-1 de meio) do meio SH (1,9 USD L-1 de meio). A estrutura das microfibrilas de celulose produzidas por Rhodococcus sp. MI 2 em meio suplementado com extrato de Cha-poo, observado por MEV, apresentou fibrilas maiores e menos congestionadas do que aquelas produzidas no meio suplementado com extrato de batata-doce. Além disso, as microfibrilas do primeiro possuíam muitos nós em forma de colmeia, enquanto os do último tinham um aspecto tipo manto ao redor das fibras.

PALAVRAS-CHAVE: Celulose bacteriana. Cha-poo. Piper sarmentosum. Batata doce. Ipomoea batatas.

\section{REFERENCES}

ADEJOYE, O. D.; ADEBAYO-TOYO, B. C.; OGUNJOBI, A. A.; OLAOYE, O. A.; FADAHUNSI, F. I. Effect of carbon, nitrogen and mineral sources on growth of Pleurotus florida, a Nigeria edible mushroom. African Journal of Biotechnology, n. 5, p. 1355-1359, 2006. 
BACKDAHL, H.; HELENIUS, G.; BODIN, A.; NANNMARK, U.; JOHANSSON, B. R.; RISBERG, B.; GATENHOLM, P. Mechanical properties of bacterial cellulose and interactions with smooth muscle cells. Biomaterials, v. 27, p. 2141-2149, 2006. https://doi.org/10.1016/j.biomaterials.2005.10.026

BAE, S.; SHODA, M. Bacterial cellulose production by fed-batch fermentation in molasses medium. Biotechnology Progress, v. 20, p. 1366-1371, 2004. https://doi.org/10.1021/bp0498490

CASTRO, C.; ZULUAGA, R.; PUTAUX, J. -L.; CARO, G.; MONDRAGON, I.; GANAN, P. Structural characterization of bacterial cellulose produced by Gluconacetobacter swingsii sp. from Colombian agroindustrial wastes. Carbohydrate Polymers, v. 84, p. 96-102, 2011.

https://doi.org/10.1016/j.carbpol.2010.10.072

FERNANDES, S. C. M.; OLIVEIRA, L.; FREIRE, C. S. R.; SILVESTRE, A. J. D.; NETO, C. P.; GANDINI, A.; DESBRIERES, J. Novel transparent nanocomposite films based on chitosan and bacterial cellulose. Green Chemistry, v. 11, p. 2023-2029, 2009. https://doi.org/10.1039/b919112g

HONG, F.; QIU, K. Y. An alternative carbon source from Konjac powder for enhancing production of bacterial cellulose in static cultures by a model strain Acetobacter aceti subsp xylinus ATCC 23770. Carbohydrate Polymers, v. 72, p. 545-549, 2008. https://doi.org/10.1016/j.carbpol.2007.09.015

IGUCHI, M.; YAMANAKA, S.; BUDHIONO, A. Bacterial cellulose a masterpiece of nature's arts. Journal of Materials Science, v. 35, n. 2, p. 261-270, 2000. https://doi.org/10.1023/A:1004775229149

ISHIHARA, M.; MATSUNAGA, M.; HAYASHI, N.; TISLER, V. Utilization of D-xylose as carbon source for production of bacterial cellulose. Enzyme and Microbial Technology, v. 31, p. 986-991, 2002.

https://doi.org/10.1016/S0141-0229(02)00215-6

KESHK, S.; RAZEK, T.; SAMESHIMA, K. Bacterial cellulose production from beet molasses. African Journal of Biotechnology, v. 5, n. 17, p. 1519-1523, 2006.

KONGRUANG, S. Bacterial cellulose production by Acetobacter xylinum strains from agricultural waste products. Applied Biochemistry and Biotechnology, v. 148, n. 1-3, p. 245-256, 2008.

https://doi.org/10.1007/s12010-007-8119-6

KUROSUMI, A.; SASAKI, C.; YAMASHITA, Y.; NAKAMURA, Y. Utilization of various fruit juices as carbon source for production of bacterial cellulose by Acetobacter xylinum NBRC 13693. Carbohydrate Polymers, v. 76, n. 2, p. 333-335, 2009. https://doi.org/10.1016/j.carbpol.2008.11.009

LI, Y.; WANG, S.; HUANG, R.; HUANG, Z.; HU, B.; ZHENG, W.; YANG, G.; JIANG, X. Evaluation of the effect of the structure of bacterial cellulose on full thickness skin wound repair on a microfluidic chip.

Biomacromolecules, v. 16, n. 3, p. 780-789, 2015. https://doi.org/10.1021/bm501680s

MOON, S.; PARK, J.; CHUN, H.; KIM, S. Comparisons of physical properties of bacterial cellulose produced in different culture conditions using saccharified food wastes. Biotechnology and Bioprocess Engineering, $v$. 11, n. 1, p. 26-31, 2006. https://doi.org/10.1007/BF02931864

MOOSAVI-NASAB, M.; YOUSEFI, M. Biotechnological production of cellulose by Gluconacetobacter xylinus from agricultural waste. Iranian Journal of Biotechnology, v. 9, p. 94-101, 2011.

NARITOMI, T.; KOUDA, T.; YANO, H.; YOSHINAGA, F. Effect of lactate on bacterial cellulose production from fructose in continuous culture. Journal of Fermentation and Bioengineering, v. 85, p. 89-95, 1998. https://doi.org/10.1016/S0922-338X(98)80012-3 https://doi.org/10.1016/S0922-338X(97)80360-1 
NOGI, M.; HANDA, K.; NAKAGAITO, A. N.; YANO, H. Optically transparent bionanofiber composites with low sensitivity to refractive index of the polymer matrix. Applied Physics Letters, v. 87, p. 87-89, 2005. https://doi.org/10.1063/1.2146056

NOGI, M.; YANO, H. Transparent nanocomposites based on cellulose produced by bacteria offer potential innovation in the electronics device industry. Advanced Materials, v. 20, p. 1849-1852, 2008.

https://doi.org/10.1002/adma.200702559

SAKAGAMI, Y.; SAWABE, A.; KOMEMUSHI, S.; ALL, Z.; TANAKA, T.; LLIYA, I.; LINUMA, M. Antibacterial activity of Stibene oligomers against vancomycin-resistant Enterococci (VRE) and methicillinresistant Staphylococcus aureus (MRSA) and their synergism with antibiotics. Biocontrol Science, v. 12, n. 1, p. 7-14, 2007. https://doi.org/10.4265/bio.12.7

SANI, A; DAHMAN, Y. Improvements in the production of bacterial synthesized biocellulose nanofibres using different culture methods. Journal of Chemical Technology and Biotechnology, v. 85, p. 151-164, 2010.

SHAH, J.; BROWN, R. M. Towards electronic paper displays made from microbial cellulose. Applied Microbiology and Biotechnology, v. 66, p. 352-355, 2005. https://doi.org/10.1007/s00253-004-1756-6

SHEZAD, O.; KHAN, S.; KHAN, T.; PARK, J. K. Physicochemical and mechanical characterization of bacterial cellulose produced with an excellent productivity in static conditions using a simple fed-batch cultivation strategy. Carbohydrate Polymers, v. 82, p. 173-180, 2010.

https://doi.org/10.1016/j.carbpol.2010.04.052

TANSKUL, S.; AMORNTHATREE, K.; JATURNLAK, N. A new cellulose-producing bacterium, Rhodococcus sp. MI 2: Screening and optimization of culture conditions. Carbohydrate Polymers, v. 92, p. 421-428, 2013. https://doi.org/10.1016/j.carbpol.2012.09.017 